\title{
FACTORS EXPLAINING THE DIVERSITY OF LAND COVER IN ABANDONED FIELDS IN A MEDITERRANEAN MOUNTAIN AREA
}

\author{
D. Peña-Angulo1*, M. Khorchani2, E. Nadal-Romero2, P. Errea2, M. Martínez-Arnáiz3, \\ T. Lasanta2
}

1 Departamento de Geografía, Instituto Universitario de Ciencias Ambientales (IUCA), Universidad de Zaragoza, Zaragoza, Spain.

2 Instituto Pirenaico de Ecología, Consejo Superior de Investigaciones Científicas (IPE-CSIC), Zaragoza, Spain.

3 Departamento de Historia, Geografía y Comunicación. Universidad de Burgos, Burgos, Spain.

*Corresponding author

\begin{abstract}
Abandoned fields form an integral part of the landscape of Mediterranean mountains. For centuries, very steep slopes with poor soils were cultivated to feed the local population. From the mid-20th century, agriculture on many slopes has been abandoned and secondary succession is taking place with environmental, socio-economic and landscape implications. This paper investigates the role of physical (climate variability and topography) and human (age of abandonment and field type - flat, sloping, terraced) factors in the process of secondary succession in abandoned fields in a representative Mediterranean mountain area. Aerial photographs from 1956 and 1978 were used to map the space-time process of land abandonment, and field types. Data on vegetation cover in abandoned fields was obtained in the SIOSE, the information system on land use in Spain (2006). The map was incorporated into a GIS and statistical analysis was done with $\mathrm{R}$ software (R, version 3.2.3).

The results show that altitude and climate variability are the principal factors explaining the distribution of areas of forest and shrub. The slope and solar radiation are less important. Human management, although apparently a lesser determinant, has a strong influence. Management before abandonment conditions the spatial distribution of the seed bank and the extent of soil degradation. Management following abandonment (afforestation of conifers, shrub clearings and livestock grazing) decides where pine forest and pastures are located. The results of our case study suggest, that unlike most of cases
\end{abstract}


in the literature, the age of abandonment is not the main factor explaining the natural succession processes. The knowledge about how natural and anthropogenic factors affect secondary succession should be considered a tool for land management in mountain areas.

Keywords: Land abandonment, secondary succession, natural revegetation, Mediterranean landscape, Spain

\section{Introduction}

Agricultural abandonment has been defined by many authors as the ceasing of agricultural activities on croplands and grasslands resulting in a secondary succession process and the recovery of natural vegetation (Prishchepov et al., 2012b; MacDonald et al., 2000; Keenleyside and Tucker, 2010, Levers, et al., 2018). Since the mid-20th century, abandonment of agricultural land is found in many regions of the world, especially North America and the Mediterranean Europe (Debussche et al., 1999; MacDonald et al., 2000; Waisamen and Bliss, 2002; Levers et al., 2018). Ramankutty and Foley (1999) calculated that, on a global scale, approximately 1.5 million $\mathrm{km} 2$ have been abandoned. Land use changes estimations indicate that, by 2030, 3-4\% of agricultural land in Europe will be abandoned (between 126,000 and 168,000 km2), according to Keenleyside and Tucker (2010), while other authors raise the numbers to 6.7\% (Rienks, 2008; Verburg and Overmars, 2009).

The first and principal effect of land abandonment is the start of a process of secondary succession, which has environmental (landscape structure, biodiversity, wildfire regime, hillside hydrology, soil erosion etc.), socio-economic (availability of pasture, livestock numbers, landscape aesthetics, etc.) implications, also for ecosystem services (carbon sequestration, water supply, tourism, etc.) (Chauchard et al., 2007; Sitzia et al., 2010; García-Ruiz and Lana-Renault, 2011; Bernués et al., 2014; Lasanta et al., 2015; Nadal-Romero et al., 2016). The process of plant colonisation is complex and gives rise to a patchwork of environments and land covers depending on several factors: age of abandonment, lithology, fertility of the soil, topography, use and management before and after abandonment, human disturbance (fire, shrub clearing, ploughing, etc.), climate conditions, soil humidity, and so on. Therefore, it is not surprising that there is extensive literature on the subject (Golley, 1977; Bunce, 1991; Pausas, 1999; Vicente-Serrano et al., 2005; Mottet et al., 2006; Gellrich et al., 2007, Zapata Pérez et al. 2016, among others) 
analysing the impact of environmental conditions and human management practices on plant colonisation.

Agricultural land covered a large area of the Mediterranean mountains in Europe until the mid-20th century. Since then, an intense process of abandonment has promoted secondary succession (Strijker, 2005; Sitzia et al., 2010; Arnáez et al., 2015; Terres et al., 2015; Lasanta et al., 2017a). Hence, abandoned fields constitute one of the most common land uses these days, with a major impact on the landscape and further environmental and socio-economic implications (Sitzia et al., 2010; García-Ruiz and Lana-Renault, 2011).

Most studies carried out on secondary succession are based on sampling from abandoned fields selected as being representative: age of abandonment (Debussche et al., 1996), lithology (Lesschen et al., 2008a; Belmonte-Serrato et al., 2016), management before and after abandonment (Molinillo et al., 1997; Cramer et al., 2008), human disturbance (pasturing, fire, etc.) (Bonet and Pausa, 2004; Teira and Peco, 2003; Rocha et al., 2016). Based on this, the causes affecting the process of succession have been analysed to provide highly interesting outcomes on temporal rhythms, the composition of species at community level and the resulting land covers. However, few studies have analysed (i.e. Padilla Blanco, 1998; Robledano Aymerich et al., 2016) the heterogeneity of plant cover on wider regional scales (valley, district, etc.), perhaps due to a lack of sufficiently detailed spatial information, and the huge effort required to work on large areas. Recent maps produced by some public administrations have enabled these limitations to be overcome. Spain has very detailed maps; the Information System on Land Use in Spain (SIOSE) displays the diversity of land covers and allows relating it to various topographical, environmental and management factors.

From a scientific point of view, it is very useful to know the land covers and its spatial distribution in secondary succession processes. It has also important implications for the environment (quantification of fire risk, water regulation, land conservation, biodiversity, etc.), for the landscape (aesthetics and heterogeneity of the landscape) and socio-economics (availability of pastures, hunting, timber, by-products of mountains, etc.). This paper aims to gain more insight into the discussion by exploring the following central research questions: which factors conditioned the present land cover in abandoned fields? This leads to the following research hypothesis: the age of abandonment is the most influencing factor in secondary succession processes. In this respect, the objectives of the paper are: (i) to analyse secondary succession processes after land abandonment in 
Cameros Viejo (La Rioja), and (ii) to determine the significance of factors affecting secondary succession after land abandonment in different land covers.

\section{Material and methods}

\subsection{Study area.}

This study was carried out in Cameros Viejo (north-west of the Iberian Mountain range), a representative area of the Mediterranean mountains in Europe (Figure 1). The Leza and Jubera valleys (Cameros Viejo) cover a surface area of $396 \mathrm{~km} 2$, rising from $600 \mathrm{~m}$ a.s.l. to 1,700 m s.a.l. (Figure 1). Cameros Viejo consists of a gentle line of peaks, rounded and with moderate slopes. The most rugged relief is in the outer zones, especially in the fringe of Mesozoic limestone joining the Iberian Mountain range with the Ebro Depression, and in the deep ravines surrounding rivers (García-Ruiz and Arnáez, 1991). Annual rainfall fluctuates between $450 \mathrm{~mm}$ in the driest places and $850 \mathrm{~mm}$ in the peaks, with maximums in spring and autumn and minimums in summer. The annual average temperature is between $10-11^{\circ} \mathrm{C}$, but significantly lower on the peaks (Cuadrat and Vicente-Serrano, 2008). Cameros Viejo has a partly Mediterranean climate with strong continental features and little influence from ocean fronts, leading to water deficit in summer, with the dryness accentuating due to the sandy texture of the soil and its shallow depth (García-Ruiz et al., 1988).

The majority of the study area falls within the Quercus pyrenaica ecosystem. However, massive deforestation in the Middle Ages confined the forest to the enclaves of more difficult access and little used for farming. During the last few decades, Pinus sylvestris, $Q$. pyrenaica and $Q$. rotundifolia subs. Ballota woods have spread, both through natural succession and reforestation, although shrub still occupies large areas. Genista scorpius, Buxus sempervirens, Rosmarinus officinalis and Thymus vulgaris are found in limestone zones. Cistus laurifolius predominates on siliceous ground (Arnáez et al., 2011) (Figure 1).

Cameros Viejo has changed recently from intense farming to sudden abandonment (Arnáez et al., 2011). The 1900 census recorded 8,013 inhabitants (20.2 per km2), while there were only 607 in 2018 (1.53 per $\mathrm{km} 2$ ). At present, hardly any crops are grown, managing the territory with extensive grazing, mainly cows, with some horses and small flocks of sheep and goats. The livestock grazes mostly around the cattle sheds in the valley bottoms or near ravines, rarely moving up the slopes, which favours secondary succession (Lasanta and Arnáez, 2009). Since 1986, the Regional Government has been 
clearing shrublands to regenerate pastures in an effort to develop extensive livestock grazing, retain the population and control wildfires (Lasanta et al., 2018; Lasanta et al., 2018). From 1986 to $2017,6,738$ ha were cleared, equivalent to $28.5 \%$ of the shrublands, and $17 \%$ of the Cameros Viejo area.

Throughout the 20th century, Cameros Viejo witnessed a severe shrinkage of farmland area. Lasanta and Arnáez (2009) showed that abandoned fields cover 15,436.6 ha (38.9\% of the total surface area). Until 1956, only $4,790.3$ ha had been abandoned (30.9\% of the previous agricultural area). Following that year, a second stage began leading up to the end of the 1970s. The speed of abandonment accelerated, with 14, 505.3 ha abandoned from 1956 to 1978 (an average of 442 ha yr-1). Abandonment of some cultivated fields has continued over the last three decades, reducing crop areas to 54.3 ha in 2006 (SIOSE, 2006). Since 2006, only 31 ha has been abandoned according to statistics of the Regional Government of La Rioja.

\subsection{Methods}

\subsubsection{Creating a database}

Aerial photographs from 1956 (scale 1:33,000) were used to delimit the agricultural area, differentiating between the cultivated and abandoned land at this time; also the field types were identified: terraces, sloping and flat. Next, using photographs from 1978 (scale 1: 18,000), a map was made of the abandoned area from 1956-1978 and that which was still cultivated in 1978, when over $99 \%$ of farmland had been abandoned. The map with the cultivated area, the age of abandonment and field types was transferred to the topographical map (scale 1: 50,000) and digitized and geo-referenced with GIS (ArcGIS 10.3). 15,029 cells were used at a resolution of $100 * 100$ metres. Most studies that use information on abandoned fields base their analysis on records starting on the 70's, due to the lack of detail data (e.g., satellite images, official inventories, etc.) from previous periods. In this study, we provide detail information regarding the state of abandoned fields in different periods: before 1956 and in the interval 1956-1978 based on aerial photographs, which provide highly valuable inputs for these purposes. It is really difficult, to identify the exact date of abandonment before 1956. Some authors indicated that at the beginning of the XX century some cultivated fields were already abandoned, however after the Spanish Civil War some fields were again cultivated due to the extreme bad conditions (Lasanta Martínez and Errea Abad, 2001). 
The land cover on abandoned farmland was given by SIOSE (Information System on Land Use in Spain) and available on www.larioja.org. This is a map showing land use and cover, at a scale of 1: 5,000, although presented at 1:25,000 refer to 2006 (see Lasanta et al., 2011 for further details). This enabled the mapping of land cover in abandoned fields before 1956, between 1956 and 1978, and between 1978 and 2006. As the SIOSE map is highly detailed, the legend is very complex, giving rise to several combinations (25 categories for abandoned fields in Cameros Viejo: Lasanta et al., 2011), which makes the results difficult to analyse and interpret. Therefore, it was decided to reclassify it into 8 categories, taking into account the surface area of each category and its own characteristics. The 8 categories defined in this paper are (Figure 2): 1. Deciduous, 2. Conifers, 3. Shrub-Deciduous, 4. Shrub-Conifers, 5. Shrub-Mixed forest (deciduous and coniferous), 6. Shrub, 7. Shrub-Pasture, 8. Pasture.

Some of the factors selected to study the distribution of land use come from the Digital Elevation Model (DEM in metres), at a resolution of 100*100 metres (GTOPO30, USGS 1996). Factors obtained from the DEM are altitude (m), orientation with 8 possible directions, slope $\left({ }^{\circ}\right)$, and potential solar radiation $(\mathrm{WH} / \mathrm{m} 2)$. Annual rainfall and the average annual temperature were obtained for the period 1970-2003 from a study by Cuadrat and Vicente-Serrano (2008), at the same DEM resolution (Table 1 and Figure 5). Other variables that has been analysed in similar studies, as lithology (Zapata-Pérez et al., 2016) and soil properties have been discarded: lithology because most of the cultivated land was included in one lithology (Cretaceous sandstones and clays) and soil properties due to the low resolution of the available information.

\subsubsection{Database analysis}

An exploratory study was made of the data to find the distribution of land cover for each of the factors (altitude, slope, solar radiation, average annual temperature, total annual rainfall, orientation, age of abandonment of fields and field type). In the preliminary analysis for quantitative variables (altitude, slope, solar radiation, average annual temperature and annual rainfall), a box diagram was used to supply information on the minimum and maximum values, quartiles, Q1, Q2 or mean and Q3, and on any atypical values and distribution symmetry. For the qualitative variables (orientation, age of abandonment and field type), a bar graph was used showing the frequency (\%) of each category defined within the variable for each type of land cover. 
In addition, a principal component analysis (PCA) (multivariate analysis) was carried out to summarize and classify factors explaining the space-time process in secondary succession (Everitt and Horton, 2011). The PCA enabled group factors with a similar influence to be grouped and later relate each of the PCA components to the current land covers. The 8 factors studied were considered as variables, and each sample in the study $(15,029$ cells) was deemed an observation. Each component of the PCA was selected according to the percentage of variance explained and defined by its correlation with the analysed factors. Results from the PCA were related to the 8 categories of land covers to determine which predominated in the factors analysed. The whole statistical analysis was done with R software ( $\mathrm{R}$ version 3.2.3) (R Development Team core 2013), and graphics with QGIS (QGIS Development Team, 2009). Finally, information about management before and after land abandonment was obtained through knowledge achieved in previous studies, field work, and meetings and interviews with regional administration and stakeholders. This information provided data about past and present land management strategies: afforestations (Ortigosa, 1991), shrub clearings and fire control (Lasanta et al., 2018).

\section{Results}

\subsection{The agricultural area and land abandonment in Cameros Viejo.}

Figure $3 \mathrm{a}$ shows the spatial distribution of abandoned fields and the age of abandonment in three different periods: before 1956, between 1956-1978, and after 1978. Figure $3 \mathrm{~b}$ shows the percentage of each type of land cover observed in 2006 related to the abandonment period. All land covers are present in the abandoned fields, without the age of abandonment being an influencing factor. Proof of this result is that there are deciduous and coniferous forests in the most recently abandoned fields (after 1978), when it could be expected that these fields would be in the earlier stages of secondary succession. Similarly, pasture is found in abandoned fields for any age, when it could be expected that they would have completed several stages of secondary succession. Areas with steep slopes were the first ones to be abandoned. Currently, those areas are populated by shrubdeciduous vegetation and pastures. In the period 1956-1978, about $15 \%$ of the cultivated area was abandoned (see also Lasanta and Arnáez, 2009). These abandoned fields correspond to zones with higher altitudes. Nowadays, these areas present a high diversity of types of land covers, with shrub-pastures and pastures being predominant. The last areas being abandoned were those in lower altitudes, in zones near the rivers and with 
gentle slopes. In these areas shrub-deciduous and pasture land convers are predominant (Figure 3b).

Figure 4a shows the spatial distribution of the field types (sloping fields, terraces and flat fields) and Figure 4b shows the percentage of land cover observed in 2006 for each field type. Sloping fields occupied $54 \%$ of this space, terraces $31 \%$, and the remaining $5 \%$ were flat fields. Cultivation had stopped on $36.5 \%$ of the surface area of sloping fields and $31.8 \%$ of terraces before 1956 . It can be observed that terraces close to the river were abandoned after 1956, while this took place earlier on the ones further away from the river and those on steeper slopes. $44.1 \%$ of the area abandoned before 1978 is on sloping fields, and $55.9 \%$ on terraces. High altitude areas were mainly cultivated with sloping fields, characterized nowadays by different land covers, especially deciduous and conifers. Cultivated areas in lower altitudes were mostly flat fields, and the predominant land covers are shrub-deciduous and pasture. Terraces presented an important growth of shrub-conifers.

\subsection{Current land covers in abandoned fields}

Table 2 includes the surface area occupied by land cover in abandoned fields in Cameros Viejo in 2006. It can be seen that shrublands (29.5\% of the total surface area) or combined with other land covers (53.8\% of the total surface area) from the matrix of the landscape. It must be pointed out that the initial stages of secondary succession predominate: pasture (12.8\%), shrub-pasture (30.9\%) and shrub (29.5\%), while very few abandoned fields have reached the deciduous $(2.6 \%)$ and coniferous $(0.9 \%)$ forest stage.

Figure 5 shows how each land cover is associated with the studied factors (a. altitude; b. mean annual temperatures; c. total annual rainfall; d. slope; e. potential radiation; f. orientation). Deciduous, conifer, shrub-deciduous and shrub-conifer categories are mainly found on the higher altitudes, with lower temperatures and higher rainfall amounts, with little solar radiation and gentle slopes. However, shrub and shrubpasture are usually at the bottom of river valleys, where temperatures are higher, rainfall lower, with more solar radiation and moderate slopes. Pasture is a special case due to its random distribution without keeping a close relationship with any of the factors analysed; there are areas of pasture at various altitudes, with very different rainfall and temperatures.

\subsection{Factors explaining the spatial distribution of land cover in abandoned fields}


Figure 6 shows the role played by the factors analysed for the spatial distribution of land cover. PC1 represents $35 \%$ of the total variance explained. It has a significant positive correlation with the temperature (0.57), and significant negative correlation with altitude and rainfall ( -0.54 and -0.47 , respectively). PC2 represents $18 \%$ of the total variance explained. It has a significant positive correlation with the age of abandonment (0.51) and slope (0.36), and a significant negative correlation with solar radiation (-0.55), orientation (-0.43) and field type (-0.35) (Figure 6a).

The PCA shows the importance of altitude. PC1 differentiates between high and low altitudes, while PC2 shows the abandoned fields at mid altitude. Spatially, (Figure 6b) it can be seen that the positive PC1, representing temperature, predominates in the bottom of river valleys; negative PC1 predominates in higher areas, together with high rainfall amounts. PC2 shows that positive values relate to the age of abandonment and slope, while the negative ones are linked to solar radiation, exposure and field type.

Figure 7 shows the relationship among PCA components and the 8 categories of land cover. It can be observed that: (i) rainfall and altitude are the main determining factors where deciduous forest is found. Also, to a lesser extent, in the shrub-forest categories. (ii) Conifers are mainly influenced by the slope and age of abandonment. (iii) Temperature is the most important factor for growth in the shrub category and, to a lesser extent, for the shrub-pasture. (iv) Distribution of the pasture category seems to be fairly strongly linked to altitude and rainfall, although its spatial distribution varies greatly.

Figure 8 shows the position of the different land covers (pixels) in the factorial plane. Even though discrimination was not successfully observed (high variability), some small differences could be highlighted only in deciduous and conifers areas. The deciduous forests are mainly distributed in the negative site of PC1 and in the positive site of PC2 (corresponding with areas with higher altitude and precipitation, higher slopes and abandonment before 1956). Most of the coniferous sites were also located in the positive site of the PC2 (higher slopes and abandonment before 1956) and distributed along the PC1 (high variability of altitude, precipitation and temperature).

\section{Discussion}

Secondary succession in abandoned fields is a dynamic process in which the natural vegetation starts to invade the space from where it was cleared for agriculture (Tatoni and Roche, 1994; Pugnaire et al., 2006). This evolution is scaled into a series of stages ranging from pioneer communities to very highly structured ones which are, in theory, multi-strata. Clements's models (Clements, 1928, 1936) suggest that succession 
in abandoned fields follows a linear progression, starting with herbaceous plants (ruderal or arvense that were present in the agricultural phase) giving way to shrub and, later, trees (Tomaselli, 1977). The consideration of the vegetation succession as a linear process has driven different studies that predict succession through the application of transition model matrixes (Korotkov et al., 2001; Benabdellah et al., 2003). However, in some cases, the forests do not manage to become established in the final stage (Lesschen et al., 2008b). Other models emphasise the key role played by local environmental conditions in not reaching the forest stage, but establishing stable dwarf bushes or shrublands (Tzanopoulos et al., 2005; Ruskule et al., 2012).

The temporal and spatial rhythm in the secondary succession process is determined by the interaction of biotic (competition among species and proximity of patches of vegetation), abiotic (rocky substrate, topography, climate conditions, soil characteristics) and anthropogenic factors, such as use and management before and after abandonment with subsequent disturbances, the age of abandonment and field type (Teira and Peco, 2003; Mottet et al., 2006; Gellrich et al., 2007; Cramer et al., 2008). In addition, it must be remembered that growing crops almost always degrades the soil, and so a time lapse is needed before fertility is restored, which can be longer with a more structured form trying to settle on abandoned fields. In fact, secondary succession occurs at the same time as edaphic conditions improve: unprotected, helophyte and poorly balanced conditions typical of the time immediately following abandonment are gradually replaced by more self-regulated environments, with greater heat and water inertia, characteristic of pre-forest conditions (Golley, 1977).

The influence of several environmental and human factors, together with the passage of time, results in a very heterogeneous cover, which can be observed in the cartography provided by SIOSE. In Cameros Viejo, 205 combinations of land covers were found, divided into associations (134), mosaics (58) and single cover (13) (Lasanta et al., 2011). However, the huge diversity of categories appearing on the maps means that speedy interpretation of land cover changes is difficult and demands reclassification of the legend - which is not easy - to simplify the number of categories, even though this would lose information on the dynamics of a process as active as secondary succession in abandoned fields (Lasanta et al., 2011). This study groups combinations of vegetation into 8 land cover categories (Figure 1).

At present, the abandoned fields in Cameros Viejo are mainly in the phase where the largest area is covered by shrub (G. scorpius on limestone and C. laurifolius on 
siliceous ground), either in monospecific formations or together with conifers, deciduous trees and pasture (Figure 2). This indicates that the change from shrub to tree cover is very slow in the study area. Barbero et al. (1990) point out that pre-forest shrub is frequently found in Mediterranean areas strongly affected by heavy disturbance from human activity. The slow rate of secondary succession in Cameros Viejo may be due to the climate (Mediterranean) with scarce rainfall, and also to the depleted soil following the cultivated period. Soils needs a very long time to recover sufficient fertility to grow oak and pine forests (Acácio et al., 2007; Nunes et al., 2010). It has been found that, in the Pyrenees and valleys in the Iberian Mountain range with an Atlantic climate, secondary succession is faster than in Cameros Viejo and reaches the forest stage sooner (Errea Abad et al., 2015). Climate conditions and degraded soil in the study area may justify the fact that the age of abandonment in this analysis is not so relevant as in other studies (Rühl and Pasta, 2007; Martínez-Duro et al., 2010; Zhang and Dong, 2010; Rocha et al., 2016).

In this research, it was found that altitude is a key factor in the timing of secondary succession, which agrees with the findings from other studies (Hengeveld, 1990; Gallego Fernández et al., 2014). Lasanta et al. (2004) concluded that, for the Spanish Pyrenees, altitude is the most decisive topographical factor in the annual and interannual dynamics of plant cover, since it controls the climate conditions and, therefore, certain biological processes in the vegetation. In Cameros Viejo, deciduous trees predominate in abandoned fields at higher altitude, while the lower slopes are covered by shrub. It must be remembered that the higher the altitude, the lower the temperature and evapotranspiration, and rainfall increases. Higher rainfall volumes in the upper areas seems to be an essential factor in speeding up the change from shrub to forest. This has also been found in the Pyrenees and the western sector of the Iberian mountain range, where rainfall is higher and temperatures lower (Vicente-Serrano et al., 2006). Moreover, it is known that the change from shrub to young forest can be rapid (20-30 years) in wet areas of Atlantic and continental Europe (Debussche et al., 1999; Ruskule et al., 2016), or slow (more than 80 years), as in the Mediterranean mountains (Bonet and Pausas, 2004; Rey Benayas et al. 2015).

The expansion of deciduous forests at higher altitudes is not only explained by spatial variation in climate conditions, but also by another two causes. On one hand, by the proximity of abandoned fields to stands of $Q$. pyrenaica. Arnáez et al. (2011) state that when agriculture was expanding fast (at the end of the 19th century - beginning of 
the 20th), the $Q$. pyrenaica forests on the higher slopes were no longer cut down. These forests acted in the revegetation process by providing plant seeds and propagules and improving the micro-environment conditions by retaining soil moisture and increasing porosity, which promoted seed germination (Debussche and Lepart, 1992; Verdú and García-Fayos, 1996, 1998; Rocha et al., 2016). In addition, the distance of the highest abandoned fields from the cattle sheds meant that grazing was less intense or non-existent (Lasanta, 2009). Livestock grazing is a factor that conditions the speed of secondary succession. With a suitable number of livestock, abandoned fields act as pasture for decades and delay colonisation by shrubs and trees (Hatfield et al., 2006). However, if livestock is limited, or there is no grazing, shrub penetrates rapidly, followed by trees, if environmental conditions permit (Tasser et al., 2007; Tzanopoulos et al., 2007; Sluiter and de Jong, 2007; Verburg and Overmars, 2009).

Shrub predominates in abandoned fields on the lower slopes, mainly due to the water deficit in summer and the sparse tree propagules close to the fields. Both circumstances extend the life of shrub in abandoned fields for decades (Rey Benayas et al., 2002; Bonet and Pausas, 2004). Other factor affecting secondary succession is soil quality (Tilman, 1987; Kopecký and Vojta, 2009; Ruskule et al., 2016). The various stages in secondary succession take place fairly rapidly in deep soils rich in organic material. However, the process is very slow on shallow and eroded soils or badly structured, even though there is sufficient rainfall for trees to grow and there are forests nearby (Verburg and Overmars, 2009; Pueyo and Beguería, 2007; Acácio et al., 2007). Soils heavily deficient in nutrients are frequently found in abandoned fields in the Mediterranean mountains since they have been cultivated for centuries without the use of fertilisers or soil conservation practices. Lasanta et al. (2017b) noted that, in the Spanish Pyrenees where some slopes were cleared for shifting cultivation, secondary succession is very slow, with scattered G. scorpius shrub remaining for at least 80 years. Nunes et al. (2010) observed that the poor content of organic matter in the soil of abandoned fields in central Portugal led to very slow plant colonisation.

Pine forests are usually found on the oldest abandoned fields, on steep slopes at mid altitude. This is explained by the reforestation of many slopes between 1940 to 1980 . During this time, the National Forest Service planted conifers in many regions that were being depopulated or abandoned. The purposes were economic (to increase wood and paper pulp production), social (to provide the means to live in mountain areas that were being depopulated) and environmental (to regulate the hydrological cycle and reduce soil 
erosion in abandoned areas) (Ortigosa et al., 1990; Calvo-Iglesias et al., 2009; Symeonakis et al., 2007). In the study area, reforestation took place on the first abandoned fields, which were those on the steepest slopes difficult to access with tractors, and also with the poorer and less fertile soils (Ortigosa, 1991).

Pastures do not show a clear spatial distribution model, although there is a slight bias towards fields at higher altitude. Human intervention also explains their location. Shrub clearing is usually done on abandoned fields, since it fulfils the land managers' main demands for an area to be cleared: less than $30 \%$ slope, covered by shrub, no trees and access for the brush-cutting machine. In addition, land managers aim to clear shrublands at different altitudes to extend the grazing period, thus explaining the pasture often found on higher altitudes where the livestock would not go if not for the cleared land, as it is far from their sheds (see more in Lasanta et al., 2009, 2016, 2019).

Some of the factors studied, such as solar radiation and slope seem to have little importance. This is because the abandoned fields are on gently sloping areas between 10$40 \%$, which reduces the role of solar radiation and slope. Some authors point out that, under highly disturbed conditions, such as those undergone in the study area with deforestation for crops and grazing after farming was abandoned, the topographical factors in secondary succession lose importance (Kadmon and Harari-Kremer, 1999; Tzanopoulos et al., 2007). However, others conclude that topography strongly affects secondary succession on rugged mountain landscapes, or in semi-arid areas on flat areas (Carmel and Kadmon, 1999; Bonet, 2004; Rülh et al., 2006).

The results from our study show a scarce importance to field types, whose influence is overshadowed by the strength of other factors, such as altitude and climate. Nevertheless, in a detailed study of Cameros Viejo, Errea Abad and Lasanta (2014) found that secondary succession takes place more rapidly in terraces than in sloping fields, and the change from pasture to shrub and the presence of the first trees occurs in a shorter time. This is explained by the better soil in terraces that helps the roots of shrubs and trees to penetrate faster. Furthermore, the higher infiltration rates improve moisture conditions and lessen hidric stress (Koulouri and Giurga, 2007; Arnáez et al., 2015). Pedroli et al. (2006) state that, on terraced slopes, plant colonisation is faster than on sloping fields, since the terraces form narrow bands, which favours the proximity to the seed bank present in the terrace, especially when the bank is covered in crop vegetation. Kouba et al. (2012) conclude that Quercus faginea lam. forests could form on abandoned terraces in the Aragonese Pyrenees (Spain) within 4-5 decades. 
Studies in secondary succession have evolved over time from conceptual and descriptive studies to others with an applied nature. Pranch and Walker (2011) show the different opportunities and utility that the studies of secondary succession offer as a tool in land management policies. For this reason, it is essential to know what and how natural and anthropogenic factors affect vegetation, in order to present this knowledge to the planning and land management.

\section{Conclusions}

Human intervention through deforestation and cultivation of slopes, followed by farmland abandonment and reforestation with conifers and livestock grazing, condition the secondary succession process, both in the spatial distribution of plant cover and the speed of growth. Physical factors, especially altitude and climate variability strongly influence the location of $Q$. pyrenaica forests on higher altitudes and areas of shrub at lower altitudes. However, secondary succession gives rise to a patchwork of plant cover, where human management (before and after abandonment) plays an essential role and explains the location of conifers in the first abandoned and steepest fields, and the random spatial distribution of pasture. However, our findings demonstrated that contrary to our hypothesis, the age of abandonment is not the most influencing factor in secondary succession processes in Cameros Viejo.

The results from this research confirm the complexity of secondary succession process in abandoned fields and open many questions on a process occurring where nature meets man, and where time and space are embedded, which generates myriad local responses to a process that occurs on a Global scale.

\section{Acknowledgements}

This research was supported by the ESPAS project (CGL2015-65569-R, funded by the State Research Agency-FEDER) and ECOHIPRO (1560/2015), funded by the Natural Parks-Ministry of Agriculture and Environment. The "Geoenvironmental Processes and Global Change" (E02_17R) was financed by the Aragón Government and the European Social Fund (ESF-FSE). Estela Nadal-Romero was the recipient of a "Ramón y Cajal" postdoctoral contract (RYC-2013-14371, Spanish Ministry of Economy and Competitiveness).

\section{References}


Acácio, V., Holmgren, M., Jansen, P.A., Schrotter, O., 2007. Multiple recruitment limitation causes arrested succession in Mediterranean cork oak systems. Ecosystems, 10: $1220-1230$.

Arnáez, J., Lana-Renault, N., Lasanta, T., Ruiz-Flaño, P., Castroviejo, J., 2015. Effects of farming terraces on hydrological and geomorphological processes. A review. Catena, 128: 122-134.

Arnáez, J., Lasanta, T., Errea, M.P., Ortigosa, L., 2011. Land abandonment, landscape evolution, and soil erosion in a Spanish Mediterrenean region. The case of Cameros Viejo. Land Degradation and Development, 22: 537-550.

Barbero, M., Bonin, G., Quezel, P., 1990. Changes and disturbances of forest ecosystems caused by human activities in western part of the Mediterranean basin. Vegetatio, 87(2): 151-173.

Belmonte-Serrato, F., Martínez-Hernández, C., Ruiz-Sinoga, J.D., 2016. Análisis de las características edáficas más significativas de las áreas abandonadas. En A. Romero Díaz (Coord.) Abandono de cultivos en la Región de Murcia. Consecuencias Ecogeomorfológicas. Editum. Ediciones de la Universidad de Murcia. Murcia pp. 4162 .

Benabdellah, B., Albrecht, K.F., Pomaz, V.L., Denisenko, E.A., Logofet, D.O., 2003. Markov chain models for forest succession in the Erzbirge, Germany. Ecological Modelling, 159: 145-160.

Bernués, A., Rodríguez-Ortega, T., Ripoll-Bosch, R., Alfnes, F., 2014. Socio-cultural and economic valuation of ecosystem services provided by Mediterranean agroecosystems. PLoS ONE 9(7): e102479.

Bonet, A., 2004. Secondary succession on semi-arid Mediterranean old fields in south eastern Spain: insights for conservation and restoration of degraded lands. Journal Arid Environments, 56: 213-233.

Bonet, A., Pausas, J., 2004. Species richness and cover along a 60-year chronosequence in old-fields of southeastern Spain. Plant Ecology, 174: 257-270.

Bunce, R.G.H., 1991. Ecological implications of land abandonment in Britain: some comparison with Europe: Options Méditerranéennes, 15: 53-59.

Carmel, Y., Kadmon, R., 1999. Effects of grazing and topography on long-term vegetation changes in a Mediterranean ecosystem in Israel. Plant Ecology, 145: 243254 
Chauchard, S., Carcaillet, C., Guibal, F., 2007. Patterns of land-use abandonment control tree-recruitment and forest dynamics in Mediterranean mountains. Ecosystems, 10: 936-948.

Calvo-Iglesias, M.S., Fra-Paleo, U., Díaz-Varela, R.A., 2009. Changes in farming system and population as drivers of land cover and landscape dynamics: the case of enclosed and semi-open field system in Northern Galicia (Spain). Landscape and Urban Planning, 90 (3-4): 168-177.

Clements, F.E., 1928. Plant Succession and Indicators. Wilson, 453 pp., New York

Clements, F.E., 1936. Nature and structure of the climax. Journal of Ecology, 24: 252284.

Cramer, V.A., Hobbs, R.J., Standisch, R.J., 2008. What's new about old fields? Land abandonment and ecosystem assembly. Trends Ecology Evolution, 23: 104-112.

Cuadrat, J.M., Vicente-Serrano, S.M., 2008. Características espaciales del clima en La Rioja modelizadas a partir de Sistemas de Información Geográfica y técnicas de regresión espacial. Zubía, 20: 119-142.

Debussche, M., Escarré, J., Lepart, J., Houssard, C., Lavorel, S., 1996. Changes in Mediterranean plant succession: olf fields revisited. Journal of Vegetation Science, 7: 519-526.

Debussche, M., Lepart, J., 1992. Establishment of woody plants in Mediterranean old fields: opportunity in space and time. Landscape Ecology, 6: 133-145.

Debussche, M., Lepart, J., Desvieux, A., 1999. Mediterranean landscape changes: evidence from old postcards. Global Ecology and Biogeography, 8: 3-15.

Errea Abad, M.P., Lasanta, T., 2014. Cambios en la cubierta vegetal de campos abandonados en función de los modelos de campos en Cameros Viejo (Sistema Ibérico). In: Arnáez, J., González-Sampériz, P., Lasanta, T. and Valero-Garcés, B.L.: Geoecología, Cambio Ambiental y Paisaje. Homenaje al Profesor José María García Ruiz. Instituto Pirenaico de Ecología (CSIC) - Universidad de La Rioja: 383-393, Arnedo.

Errea Abad, M.P., Nadal-Romero, E., Lasanta, T., 2015. La complejidad de la cubierta vegetal en los campos abandonados del valle de Aísa (Pirineo Aragonés). Un análisis del papel de los tipos de campos. In: de la Riva, J., Ibarra, P., Montorio, R., Rodrigues, M. (Eds.): Análisis espacial y representación gráfica: innovación y aplicación. Universidad de Zaragoza-AGE: 933-942 pp., Zaragoza. 
Everitt, B., Horton, R., 2011. An Introduction to Applied Multivariate Analysis with R. Springer, New York.

Gallego Fernández, J.B., García-Mora, M.R., García-Novo, F., 2014. Vegetation dynamics of Mediterranean shrubland in former cultural landscape at Grazalema Mountains, South Spain. Plant Ecology, 172: 83-94.

García-Ruiz, J.M., Arnáez, J., 1991. Mapa geomorfológico de Munilla (hoja 242; escala 1:50.000). Geoforma Ediciones. 26 pp., Logroño.

García-Ruiz, J.M., Lana-Renault, N., 2011. Hydrological and erosive consequences of farmland abandonment in Europe, with special reference to the Mediterranean regionA review. Agriculture, Ecosystems and Environment, 140: 317-338.

García-Ruiz, J.M., Lasanta, T., Sobrón, I., 1988. Problemas de evolución geomorfológica en campos abandonados: el valle del Jubera (Sistema Ibérico). Zubía, 6: 99-114.

Gellrich, H., Baur, P., Koch, B., Zimmermann, N.E., 2007.Agricultural land abandonment and natural forest re-growth in the Swiss mountains: A spatial explicit economic analysis. Agriculture, Ecosystems and Environment, 118(1-4): 93-108.

Golley, F. (ed.), 1977. Ecological succession. Benchmark Papers in Ecology, vol., 5. Stroudsburg, Pennsylvania.

Hatfield, R., Davies, J., Wane, A., Kerven, C., Dutilly-Diane, C., Biber, J.P., Merega, J.L., Odhiambo, M.O., Behnke, R., Gura, S., 2006. Global review of the economics of pastoralism. Review Literature and System, 1, 327-356.

Hengeveld, R., 1990. Dynamics biogeography. Cambridge Studies in Ecology. Cambridge University Press, Cambridge.

Kadmon, R., Harari-Kremer, R., 1999. Landscape-scale regeneration dynamics of disturbed Mediterranean maquis. Journal Vegetation Science, 10: 393-402.

Keenleyside, C., Tucker, G.M., 2010. Farmland abandonment in the EU: an assessment of trends and prospects. Report prepared for WWF. Institute for European Environmental Policy: 99 pp., London

Kopecký, M., Vojta, J., 2009. Land use legalicies in post-agricultural forest in the Donpovské Mountains, Czech Republic. Applied Vegetation Science, 12: 251-260.

Korotkov, V.N., Logofet, D.O., Loureau, M., 2001. Succession in mixed boreal forest of Russia: markov models and non-Markov effects. Ecological Modelling, 142: 25-38.

Kouba, Y., Camarero, J.J., Alados, C.L., 2012. Roles of land-use and climate change on the establishment and regeneration dynamics of Mediterranean semi-deciduous oak forest. Forest Ecology and Management, 274: 143-150. 
Koulouri, M., Giurga, C.H., 2007. Land abandonment and slope gradient as key factors of soil erosion in Mediterranean terraced lands. Catena, 69: 274-281.

Lasanta, T., Arnáez, J. (Eds), 2009. Gestión, usos del suelo y paisaje en Cameros. Universidad de La Rioja e Instituto de Estudios Riojanos: 191-222, Logroño.

Lasanta, T., Arnáez, J., Errea, M.P., Ortigosa, L., Ruiz-Flaño, P., 2009. Mountain pastures, environmental degradation, and landscape remediation: The example of a Mediterranean policy initiative. Applied Geography, 29: 308-319.

Lasanta, T., Arnáez, J., Pascual, N., Ruiz-Flaño, P., Errea, M.P., Lana-Renault, N., 2017a. Space-time process and drivers of land abandonment in Europe. Catena, 149(3): 810823.

Lasanta, T., Errea Abad, M.P., Vicente-Serrano, S.M., Arnáez, J., 2011. La diversidad de la cubierta vegetal en campos abandonados del Leza y Jubera (Sistema Ibérico, La Rioja) a partir del SIOSE. Zubía. Monográfico, 23: 55-78.

Lasanta, T., Khorchani, M., Pérez-Cabello, F., Errea, P., Sáenz-Blanco, R., NadalRomero, E., 2018. Clearing shrubland and extensive livestock farming: active prevention to control wildfires in the Mediterranean mountains. Journal of $\begin{array}{lll}\text { Environmental 256-266. } & \text { 227: Management }\end{array}$ https://doi.org/10.1016/j.jenvman.2018.08.104

Lasanta, T., Nadal-Romero, E., Arnáez, J., 2015. Managing abandoned farmland to control the impact of re-vegetation in the environments: The estate of the art in Europe. Environmental Science and Policy, 52: 99-109.

Lasanta, T., Nadal-Romero, E., Errea, M.P. 2017b. The footprint of marginal agriculture in the Mediterranean mountain landscape: An analysis of the Central Spanish Pyrenees. Science of the Total Environment, 599-600: 1823-1836.

Lasanta, T., Nadal-Romero, E., Errea, M.P., Arnáez, J., 2016. The effects of landscape conservation measures in changing landscape patterns: a case study in Mediterranean mountain. Land Degradation and Development, 27: 373-386.

Lasanta, T., Nadal-Romero, E., García-Ruiz, J.M., 2019. Clearing shrubland as a strategy to encourage extensive livestock farming in the Mediterranean mountains. Cuadernos de Investigación Geográfica 45. http://dx.doi.org/10.18172/cig.3616

Lasanta, T., Vicente-Serrano, S.M., Romo, A., 2004. Influencia de la topografía en la estacionalidad de la actividad vegetal: análisis en el Pirineo occidental aragonés a partir de imágenes de satélite NOAA-AVHRR. Boletín de la Asociación de Geógrafos Españoles, 38: 175-197. 
Lasanta Martínez, T. and Errea Abad, M.P., 2001. Despoblación y marginación en la Sierra Riojana. Instituto de Estudios Riojanos. Colección Ciencias de la Tierra, 9: 181 pp., Logroño.

Lesschen, J.P., Cammeraat, L.H., Nieman, T., 2008a. Erosion and terrace failure due to agricultural land abandonment in a semi-arid environment. Earth Surface Processes and Landforms, 33: 1574-1584.

Lesschen, J.P., Cammeraat, L.H., Kooijman, A.M., van Wesemael, B., 2008b. Development of spatial heterogeneity in vegetation and soil properties after land abandonment in a semi-arid ecosystem. Journal Arid Environment, 72: 2082-2092.

Levers, C., Schneider, M., Prishchepov, A.V., Estel, S., Kuemmerle, T., 2018. Spatial variation in determinants of agricultural land abandonment in Europe. Science of the Total Environment 644: 95-111

MacDonald, D., Crabtree, J.R., Wiesinger, G., Dax, T., Stamou, N., Fleury, P., GutiérrezLazpita, J.G., Gibon, A., 2000. Agricultural abandonment in mountain areas of Europe: environmental consequences and policy response. Journal Environment Management, 59: 47-69.

Martínez-Duro, E., Ferrandis, P., Escudero, A., Luzuriaga, A.L., Herranz, J.M., 2010. Secondary old-field succession in an ecosystem with restrictive soils: does time from abandonment matter?. Applied Vegetation Science, 13: 234-248.

Molinillo, M., Lasanta, T., García-Ruiz, J.M., 1997. Managing degraded landscape after farmland abandonment in the Central Spanish Pyrenees. Environmental Management, 21: $587-598$.

Mottet, A., Ladet, S., Coque, N., Gibón, A., 2006. Agricultural land-use change and its drivers in mountain landscapes: A case study in the Pyrenees. Agriculture, Ecosystems and Environment, 114: 296-310.

Nadal-Romero, E., Cammeraat, E., Pérez-Cardiel, E., Lasanta, T., 2016. How do soil organic carbon stocks change after cropland abandonment in Mediterranean humid mountain areas? Science of the Total Environment, 566-5567: 741-752.

Nunes, A., Coelho, C., Almeida, A., Rodríguez, A., 2010. Soil erosion and hydrological response to land abandonment in a central inland area of Portugal. Land Degradation and Development, 21: 260-273.

Ortigosa, L.M., 1991. Las repoblaciones forestales en La Rioja: resultados y efectos geomorfológicos. Geoforma Ediciones: 149 pp., Logroño. 
Ortigosa, L., García-Ruiz, J.M., Gil, E., 1990. Land reclamation by reforestation in the Central Pyrenees. Mountain Research and Development, 10(3): 281-288.

Padilla Blanco, A., 1988. Colonización vegetal en campos abandonados de la provincial de Alicante. Publicaciones de la Universidad de Alicante: 365 pp., Murcia.

Pausas, J.G., 1999. Mediterranean vegetation dynamics: modelling problems and functional types. Plant Ecology, 140 (1): 27-39.

Pedroli, B., Pinto-Correia, T., Cornish, P., 2006. Landscape -what's in it? Trends in European landscape science and priority themes for concerted research. Landscape Ecology, 21: 421-430.

Prach, K., Walker, L.R., 2011. Four opportunities for studies of ecological succession. Trends in Ecology and Evolution, 26 (3): 119 - 123.

Prishchepov, A.V., Radeloff, V.C., Baumann, M., Kuemmerle, T., 2012b. Effects of institutional changes on land use: agricultural land abandonment during the transition from state-command to market-driven economies in post-soviet Eastern Europe. Environmental Research Letters, 7, 024021. https://doi.org/10.1088/17489326/7/2/024021.

Pueyo, Y., Beguería, S., 2007. Modelling the rate of secondary succession after farmland abandonment in a Mediterranean mountain area. Landscape and Urban Planning, 83: 245-254.

Pugnaire, F.I., Luque, M.T., Armas, C., Gutiérrez, L., 2006. Colonization processes in semiarid Mediterranean old-fields. Journal of Arid Environments, 65: 591-603.

QGIS Development Team, 2009. QGIS Geographic Information System. Open Source Geospatial Foundation. URL http://qgis.osgeo.org

Ramankutty, N., Foley, J.A., 1999. Estimating historical changes in global land cover: Croplands from 1700 to 1992. Global Biogeochemical Cycles, 13: 997-1027.

Rey Benayas, J.M., López Pinto, A., García, C., de la Cámara, N., Strasser, R., GómezSal, A., 2002. Early establishment of planted Retama sphaerocarpa seeding under different levels of light, water and weed competition. Plant Ecology, 159: 201-209.

Rey-Benayas, J.M., Martínez-Baroja, L., Pérez-Camacho, L., Villar-Salvador, P., Holl, K.D., 2015. Predation and aridity slow down the spread of 21-year-old planted Woodland islets in restored Mediterranean farmland. New Forest, 46: 841-853.

Rienks, W.A. (Ed.), 2008. The future of rural Europe an anthology based on the results of the Eururalis study. Wageningen University Research and Netherlands Environmental assessment Agency. 
Robledano Aymerich, F., Zapata Pérez, V.M., Martínez López, V., García Meseguer, A.J., García Castellanos, F.A., Zamora López, A., Pérez Navarro, M.A., 2016. Indicadores de biodiversidad en campos abandonados: flora y fauna. In: A. Romero Díaz (Coord.) Abandono de cultivos en la Región de Murcia. Consecuencias Ecogeomorfológicas. Editum. Ediciones de la Universidad de Murcia. Murcia pp. 111137.

Rocha, G.P.E., Viera, D.L.M., Simon, M.F., 2016. Fast natural regeneration in abandoned pastures in southern Amazonia. Forest Ecology and Management, 370: 93-101.

Rülh, J., Pasta, S., 2007. Plant succession on Sicilian terraces. Annali di Botanica nova serie, 7: 111-126.

Rülh, J., Pasta, S., Schnitter, M., 2006. A chronosequence study of vegetation dynamics on abandoned vine and caper terraces of Pantelleria Island (Sicily). Archives of Nature Conservation and Landscape Research, 45(1): 71-94.

Ruskule, A., Nikodemus, O., Kasparinskis, R., Brumelis, G., 2012. Patterns of afforestation on abandoned agriculture land in Latvia. Agroforestry Systems, 85(2): 215-231.

Ruskule, A., Nikodemus, O., Kasparinskis, R., Prizavoite, D., Bojare, D., Brumelis, G., 2016. Soil-vegetation in abandoned farmland within the temperate region of Europe. New Forest, 47: 587-605.

Sitzia, T., Semenzato, P., Trentanovi, G., 2010. Natural reforestation is changing spatial patterns of rural mountain and hill landscapes: A global overview. Forest Ecology and Management, 259: 1354-1362.

Sluiter, R., de Jongs, S.M., 2007. Spatial patterns of Mediterranean land abandonment and related land cover transition. Landscape Ecology, 22: 559-576.

Strijker, D., 2005. Marginal lands in Europe - causes of decline. Basic Applied Ecology, 6: 99-106.

Symeonakis, E., Calvo-Cases, A., Arnau-Rosalen, E., 2007. Land use change and land degradation in southeastern Mediterranean Spain. Environmental Management, 40(1): 80-94.

Tasser, E., Walde, J., Tappeiner, U., Teutsch, A., Noggler, W., 2007. Land-use changes and natural reforestation in the Eastern Central Alps. Agriculture, Ecosystems and Environment, 118: 115-129.

Tatoni, T., Roche, P., 1994. Comparison of old-field and forest revegetation dynamics in Provence. Journal Vegetation Science, 5: 295-302. 
Teira, A.G., Peco, B., 2003. Modelling oldfield species richness in a mountain area. Plant Ecology, 166(2): 249-261.

Terres, J.M., Scacchiafichi, L.N., Wania, A., Ambar, M., Anguiano, E., Buckwell, A., Coppola, A., Gocht, A., Källström, H.N., Pointereau, P., Strijker, D., Visek, L., Vranken, L., Zobena, A., 2015. Farmland abandonment in Europe: identification of drivers and indicators, and development of a composite indicator of risk. Land Use Policy, 49: 20-34.

Tilman, D., 1987. Secondary succession and the pattern of plant dominance along experimental nitrogen gradients. Ecological Monographs, 57: 189-214.

Tomaselli, R., 1977. Degradation of the Mediterranean maquis. In: Mediterranean Forest and Maquis: Ecology, Conservation and Management. UNESCO.

Tzanopoulos, J., Mitchley, J., Pantis, J., 2005. Modelling the effects of human activity semi-natural vegetation of a north-east Mediterranean island (Sifnos): the development of degradation models. Applied Vegetation Science, 8: 27-38.

Tzanopoulos, J., Mitchley, J., Pantis, J., 2007. Vegetation dynamics in abandoned crop fields on a Mediterranean island: development of succession model and estimation of disturbance thresholds. Agriculture, Ecosystems and Environment, 83: 83-94.

Verburg, P.H., Overmars, K.P., 2009. Combining top-down and bottom-up dynamics in land use modeling: exploring the future of abandoned farmlands in Europe with the Dyna-CLUE model. Landscape Ecology, 25(2): 217-232.

Verdú, M., García-Fayos, P., 1996. Nucleation processes in a Mediterranean birddispersion plant. Functional Ecology, 10: 275-280.

Verdú, M., García-Fayos, P., 1998. Old-field colonization by Daphne gnidium: distribution and spatial dependence at different scales. Journal of Vegetation Science, 9: 713-718.

Vicente-Serrano, S.M., Beguería, S., Lasanta, T., 2006. Diversidad espacial de la actividad vegetal en campos abandonados del Pirineo Central español: análisis de los procesos de sucesión mediante imágenes Landsat (1984-2001). Pirineos, 161: 59-84.

Vicente-Serrano, S.M., Lasanta, T., Romo, A., 2005. Analysis of spatial and temporal evolution of vegetation cover in the Spanish Central Pyrenees: Role of human management. Environmental Management, 34(6): 802-818.

Waisamen, P.J., Bliss, N.B., 2002. Changes in population and agricultural land in conterminous United States counties, 1790-1997. Global Biogeochemical Cycles, 16: $1-19$. 
Zapata Pérez, V.M., Robledano Aymerich, F., Martínez López, V., 2016. Dinámica recolonizadora de la vegetación en campos abandonados de la Región de Murcia. In A. Romero Díaz (Coord.) Abandono de cultivos en la Región de Murcia. Consecuencias Ecogeomorfológicas. Editum, Ediciones de la Universidad de Murcia. Murcia pp. 139-159.

Zhang, J.T., Dong, Y., 2010. Factors affecting species diversity of plant communities and the restoration process in the loess area of China. Ecological Engineering, 36: 345350. 
Table 1: Factors analysed, type of variable and basic statistics.

\begin{tabular}{|c|c|c|}
\hline Factors analysed & Type & Basic statistics \\
\hline Elevation $(\mathrm{m})$ & \multirow{5}{*}{$\begin{array}{l}\stackrel{0}{\stackrel{\Xi}{\Xi}} \\
. \stackrel{\Xi}{\Xi} \\
\stackrel{\Xi}{\Xi}\end{array}$} & Min: 585 Max: 1425 Average: 1053 \\
\hline Slope $\left({ }^{\circ}\right)$ & & Min: 0.10 Max: 35 Average: 13 \\
\hline $\begin{array}{l}\text { Potential solar radiation } \\
\left(\mathrm{WH} / \mathrm{m}_{2}\right)\end{array}$ & & Min: $4 * 105$ Max: $1 * 10_{6}$ Average: $1 * 10_{6}$ \\
\hline $\begin{array}{l}\text { Average annual temperature } \\
\left({ }^{\circ} \mathrm{C}\right)\end{array}$ & & Min: 8 Max: 12 Average: 10 \\
\hline Annual rainfall $(\mathrm{mm})$ & & Min: 510 Max: 745 Average: 630 \\
\hline Orientation & \multirow{3}{*}{ 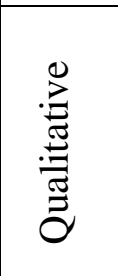 } & $\mathrm{N}, \mathrm{S}, \mathrm{E}, \mathrm{W}, \mathrm{SE}, \mathrm{SW}, \mathrm{NE}, \mathrm{NW}$ \\
\hline Field type & & Sloping (1); Flat (2); Terraced (3) \\
\hline $\begin{array}{l}\text { Age of abandonment of the } \\
\text { field }\end{array}$ & & $\begin{array}{l}\text { Before } 1956(1) \text {; Between 1956-1978 (2); } \\
\text { After } 1978(3)\end{array}$ \\
\hline
\end{tabular}

Table 2: Distribution of land cover in abandoned fields in Cameros Viejo.

\begin{tabular}{|l|c|c|}
\hline \multicolumn{1}{|c|}{ Land covers } & Surface area (ha) & Percentage (\%) \\
\hline Deciduous & 395.6 & 2.6 \\
\hline Conifers & 136.8 & 0.9 \\
\hline Shrub - Deciduous & 604.2 & 3.9 \\
\hline Shrub- Conifers & 477.1 & 16.3 \\
\hline Shrub - mixed forest & $2,523.5$ & 29.5 \\
\hline Shrub & 4,556 & 30.9 \\
\hline Shrub - Pasture & $4,772.2$ & 12.8 \\
\hline Pasture & $1,970.6$ & $\mathbf{1 0 0}$ \\
\hline \multicolumn{1}{c|}{ TOTAL } & $\mathbf{1 5 , 4 3 6}$ & $\mathbf{4}$ \\
\hline
\end{tabular}

Source: Government of Spain. Ministry of Public Works. SIOSE. Compiled by the author from SIOSE (2006) 
Figure 1. The study area and land cover distribution in 2006. 1. Deciduous (Quercus pyrenaica and Q. rotundifolia), 2. Conifers (Pinus sylvestris), 3. Shrub-Deciduous, 4. Shrub-Conifers, 5. Shrub-Mixed forest (deciduous and coniferous), 6. Shrub (Cistus laurifolius on siliceous ground and Genista scorpius, Buxus sempervirens, Rosmarinus officinalis and Thymus vulgaris), 7. Shrub-Pasture, 8. Pasture. Source: Own elaboration from SIOSE (2006).

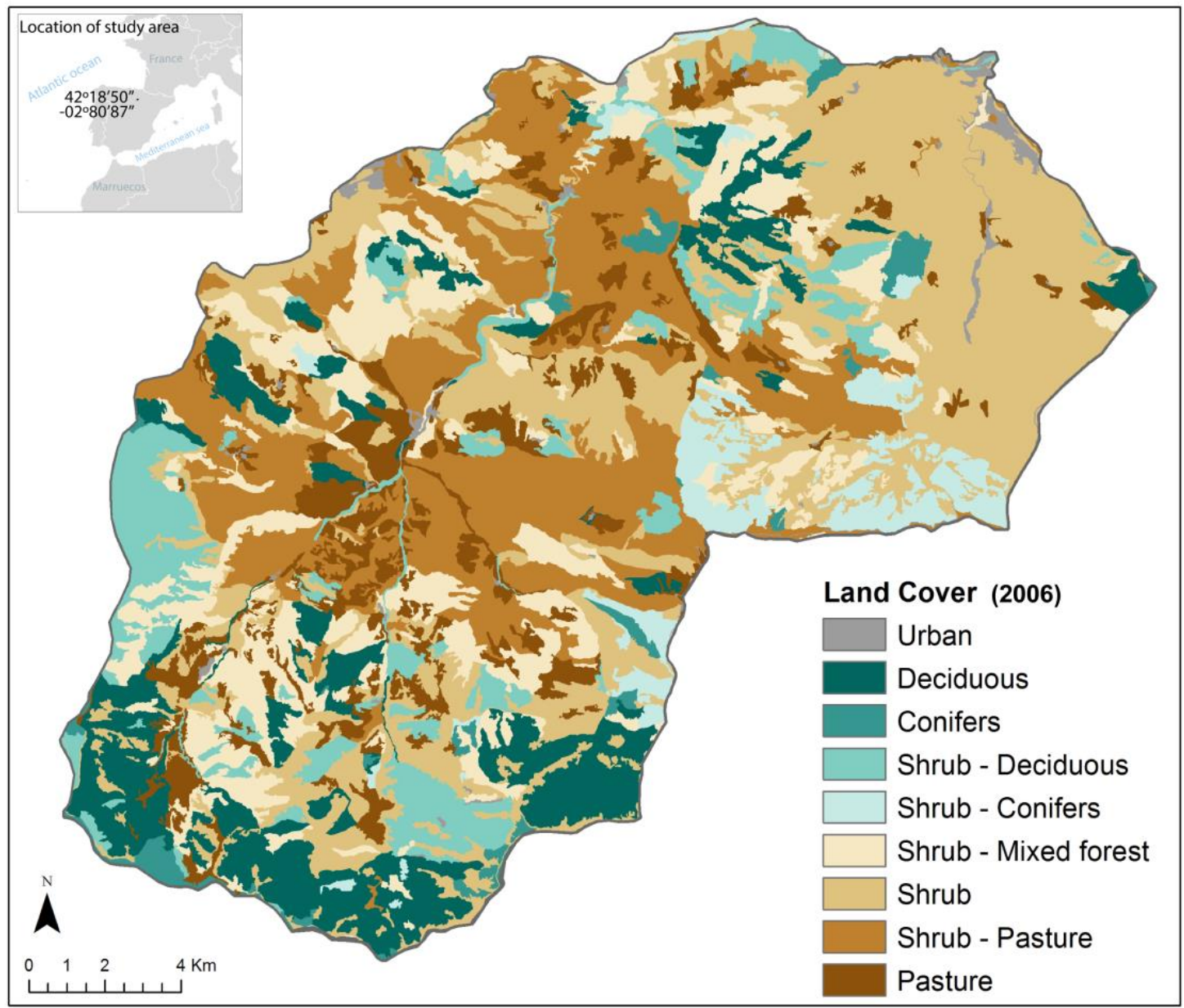


Figure 2. Spatial distribution of land cover in abandoned fields in Cameros Viejo. Source: Own preparation from digitization of aerial photographs of the corresponding year (1978) on the SIOSE cartography (2006)

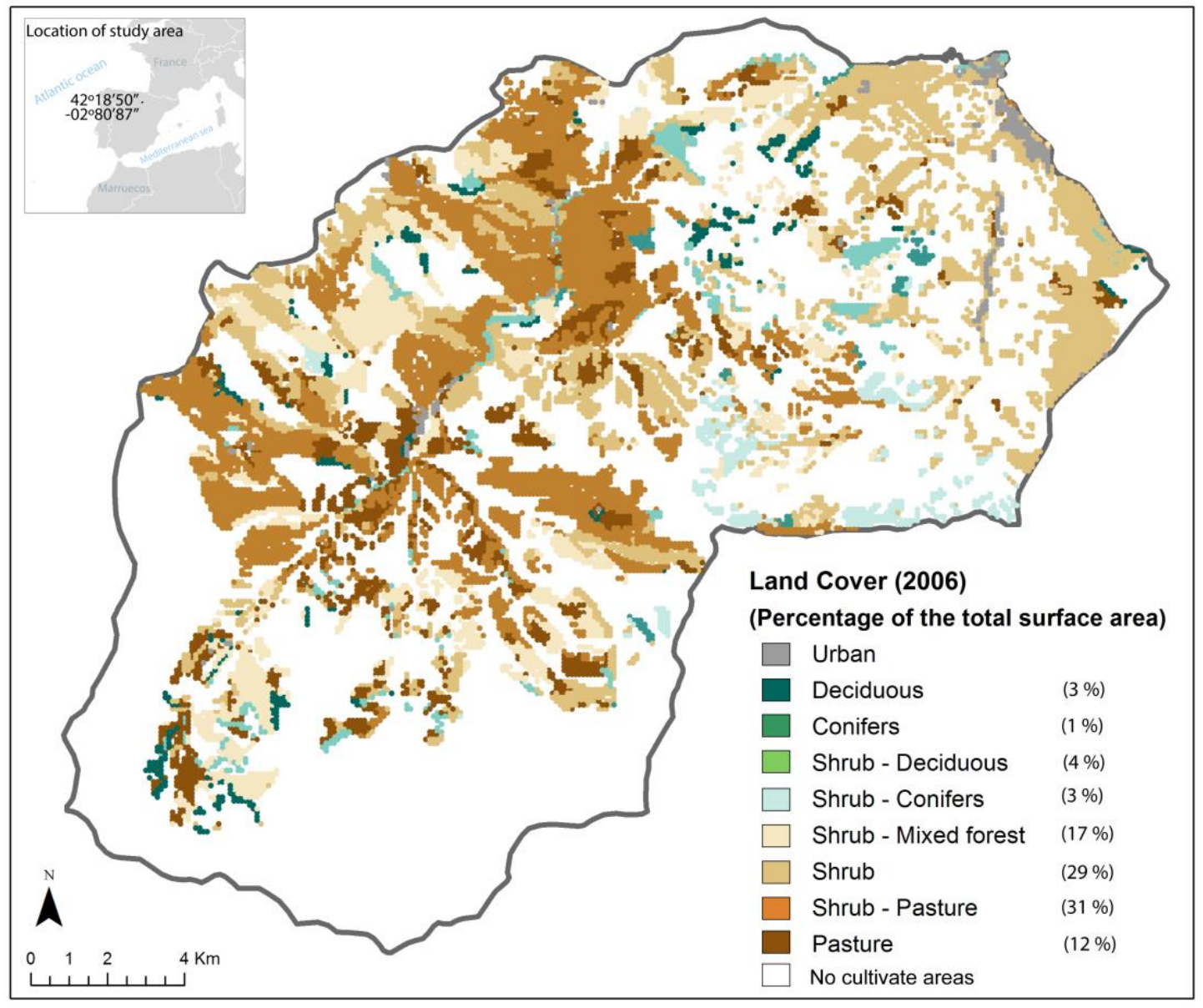


Figure 3. a.) Age of abandonment of cultivated fields and b.) Land cover in abandoned fields related to the age of abandonment.

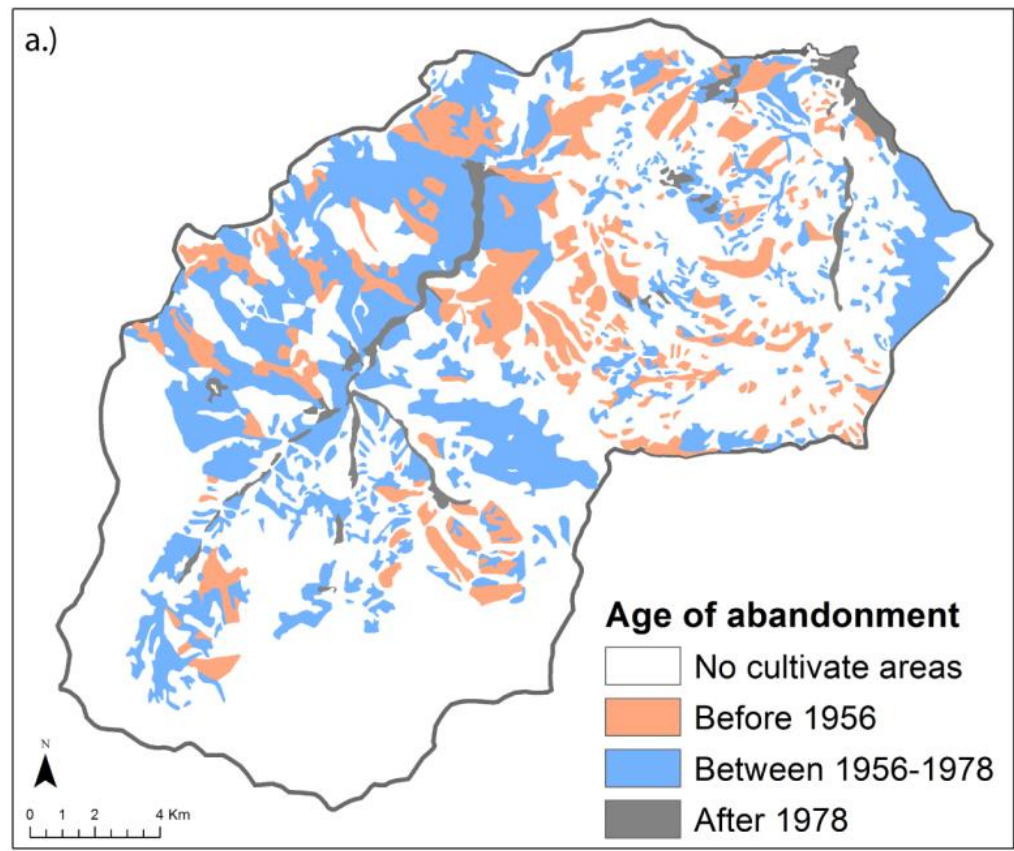

b.) $\quad$ | Before 1956 - Between 1956-1978 | After 1978

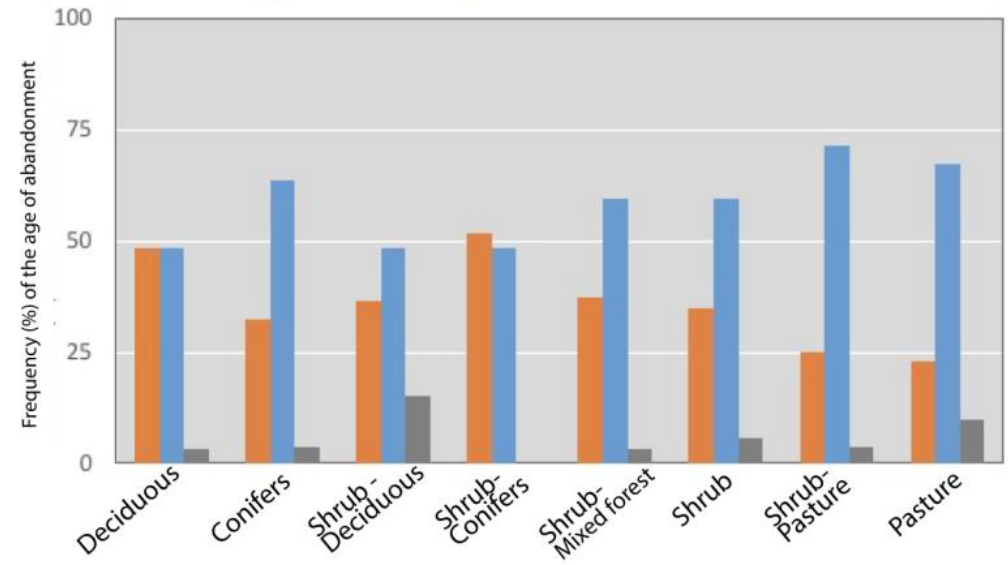


Figure 4. a.) Field types and b.) Land cover in the various field types.



b.)

- Sloping fields Terraces Flat fields

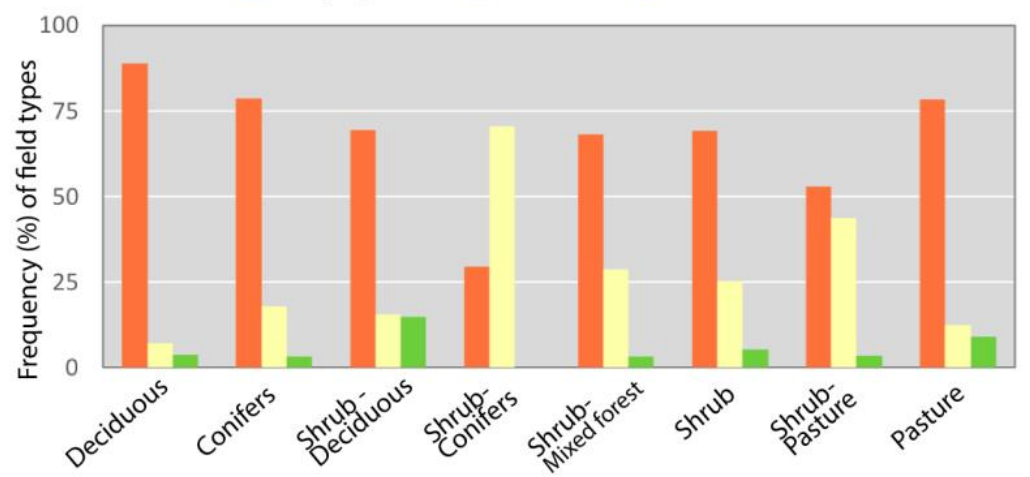


Figure 5. Spatial distribution of the land cover in abandoned fields, according to physical factors: a.) Altitude, b.) Average annual temperature, c.) Annual rainfall, d.) Slope, e.) Solar radiation, f.) Orientation.

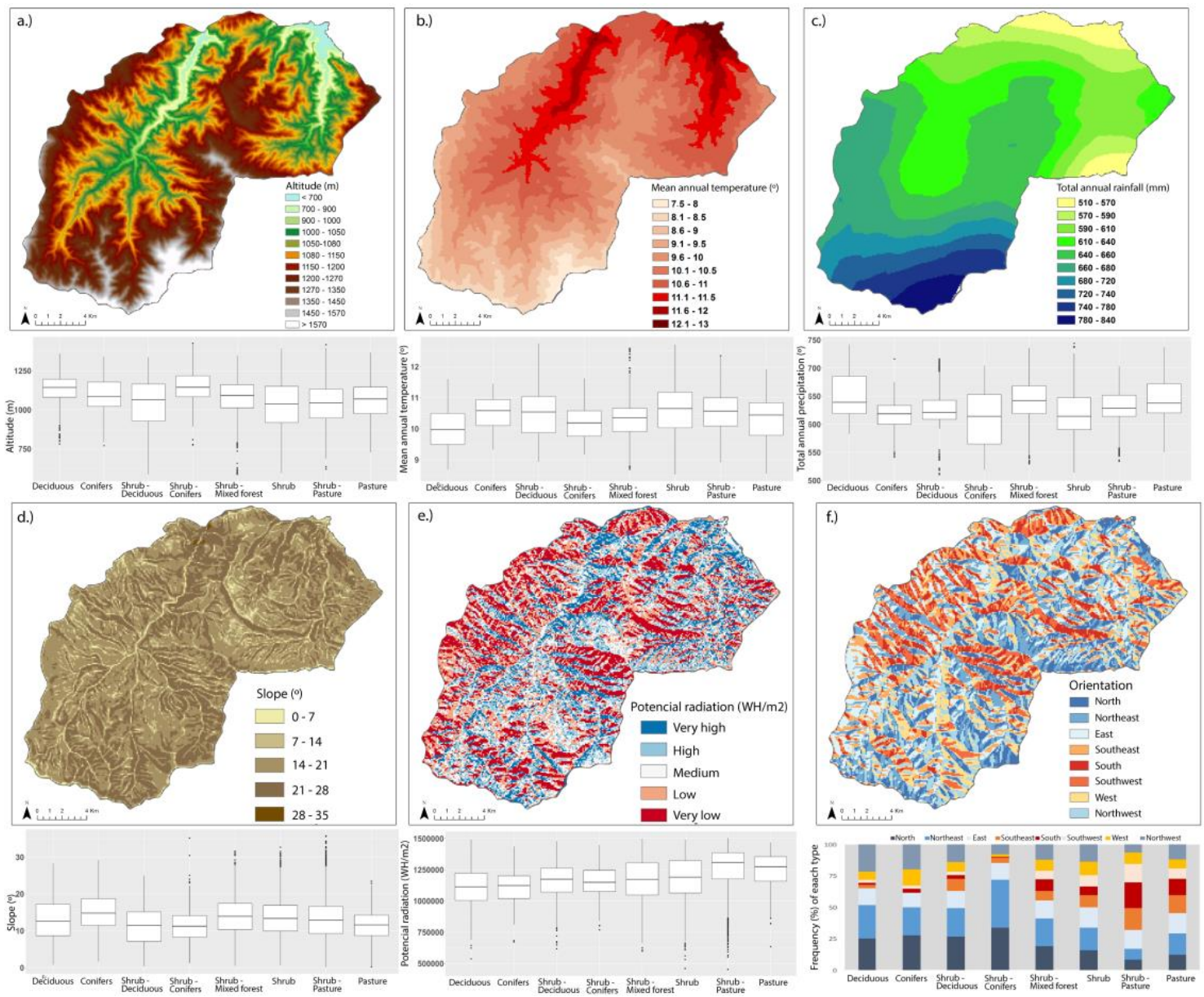


Figure 6. a.) Components on the PCA of factors studied, b.) Spatial distribution of the PCA components.

Figure 7. Distribution of land cover within PCA components

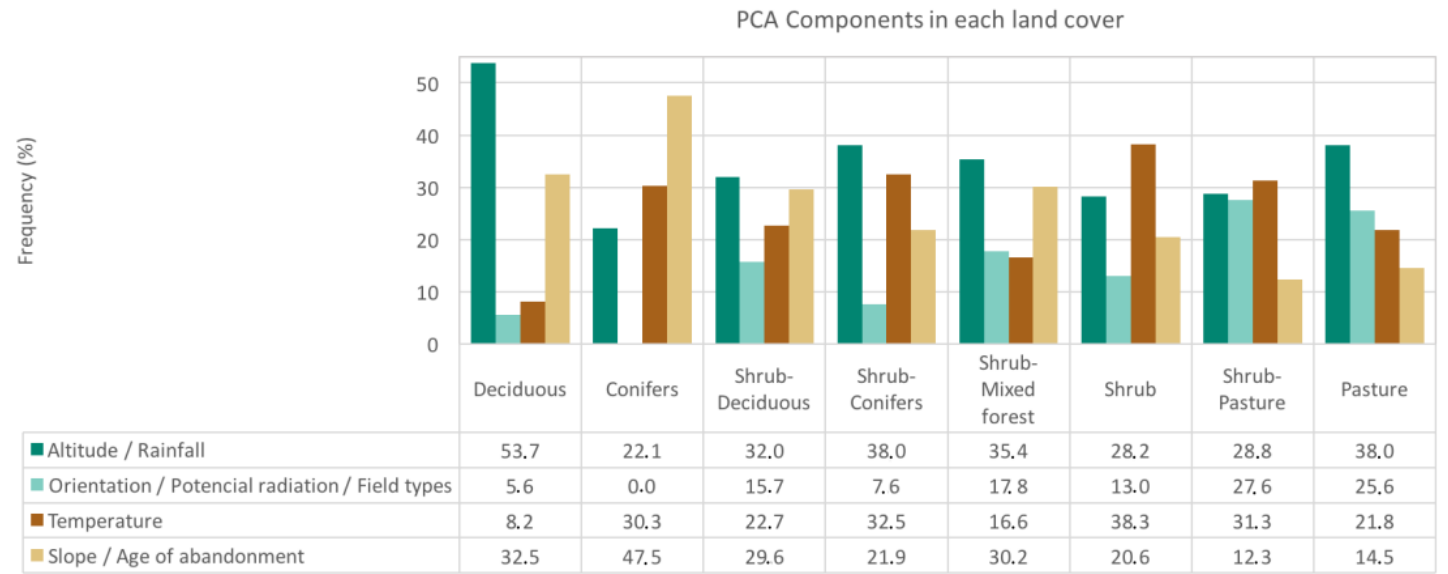


Figure 8. Distribution of land cover within PCA components in the factorial plane.
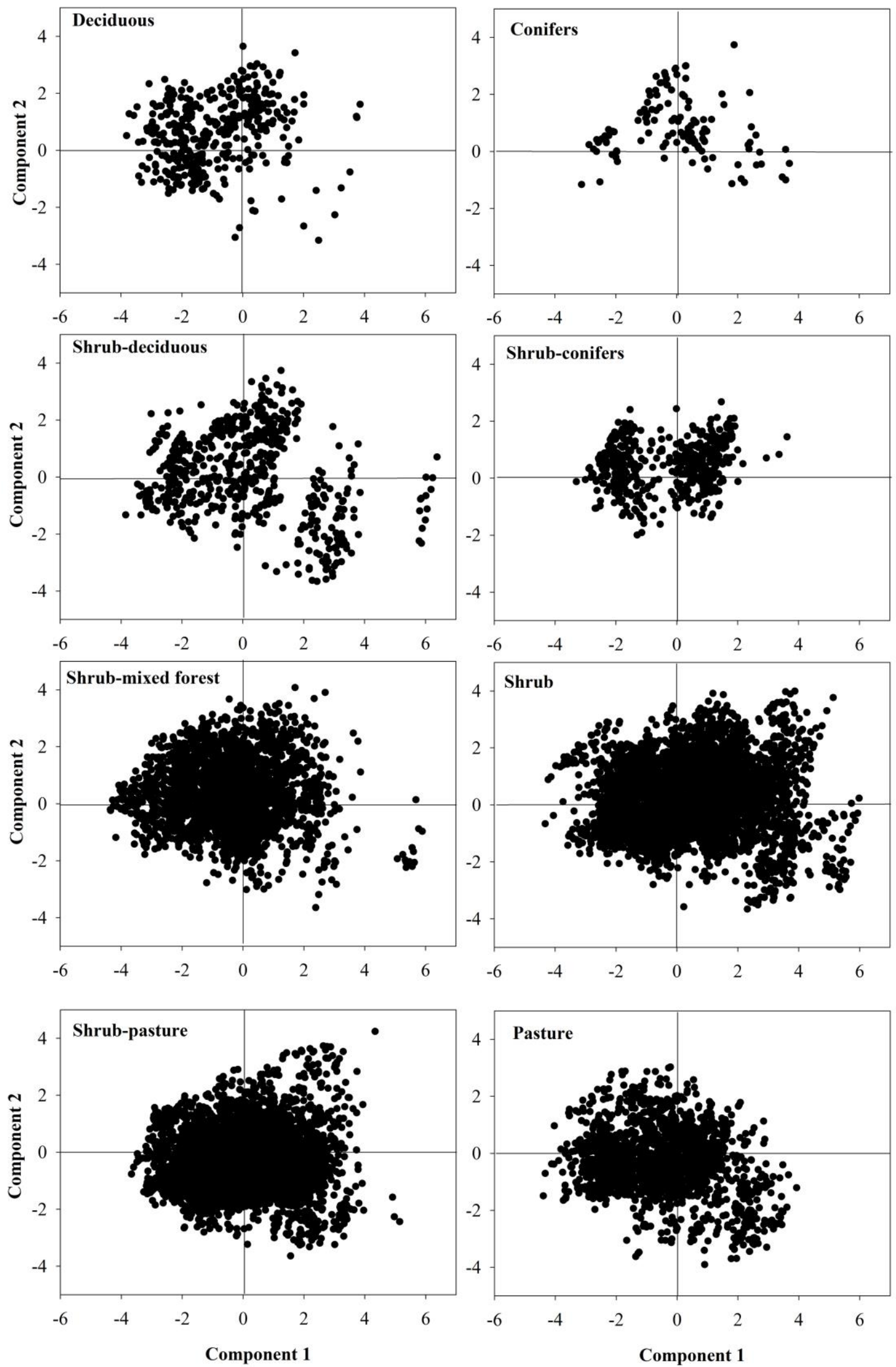
